\title{
Carbon Footprint Analysis of Municipalities - Evidence from Greece
}

\author{
K. Angelakoglou*, G. Gaidajis, K. Lymperopoulos and P. N. Botsaris \\ Department of Production Engineering and Management, School of Engineering, Democritus University of Thrace, Xanthi, Greece.
}

Received 23 October 2014; Accepted 19 November 2015

\begin{abstract}
The economical crisis that hit Greece after 2009, significantly affected its energy consumption profile due to the increased price of domestic heating oil and gasoline. The specific study aims at the quantification of the carbon dioxide emissions in municipal level due to energy and fuel consumption. Three different municipalities in North Greece (Kavala, Alexandroupolis and Drama) were assessed with the application of three different carbon footprint estimation approaches in each one of them, including two life cycle assessment methods. Results ranged from 511,799 to 571,000,

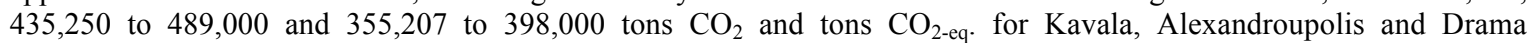
respectively. The analysis per energy type indicated the electrical energy consumption as the key factor affecting the results due to the relatively high $\mathrm{CO}_{2}$ emission coefficient of the electricity produced in Greece. The analysis per sector indicated that a percentage of nearly $75 \%$ of the total carbon footprint is assigned to the building sector whereas the private and commercial transport is accountable for the rest. Municipal activities (buildings, facilities, lighting and fleet) contributed to a small percentage to the total carbon footprint (approx. 3-8\%).
\end{abstract}

Keywords: carbon dioxide; sustainability; environmental assessment; life cycle development; policy development.

\section{Introduction}

The concept of carbon footprint (CF), namely the greenhouse gases expressed in carbon dioxide equivalents, emitted during the life cycle of an examined system, has been known for several decades as an indicator for assessing the impact of human activities to global warming potential [1]. Despite the fact that carbon dioxide is a natural component of air, high concentrations or exposure over a long time period can cause significant problems in human health [2]. CF estimation is helpful for the efficient management of greenhouse gas emissions and the evaluation of measures to reduce them. CF analysis can identify significant sources of emissions and prioritize the areas with the greatest potential for improvement, thereby increasing environmental efficiency and optimizing financial costs of amelioration actions. Several tools for $\mathrm{CF}$ calculation are available in current literature [3].

Apart from the widespread use of the term as a contribution factor to global warming and climate change, there are several confusions regarding its definition and its content [4,5]. One of the key arguing points of $\mathrm{CF}$ calculation methods is the lack of uniformity in the selection of the boundaries of the study (e.g. the inclusion or not of indirect impacts). Despite the differences among calculations, the equivalent tones of carbon dioxide ( $\mathrm{CO}_{2-}$ eq.) have been recognized as the basic functional unit of $\mathrm{CF}$ [6].

\footnotetext{
* E-mail address: kangelak@pme.duth.gr ISSN: 1791-2377 @ 2015 Kavala Institute of Technology. All rights reserved.
}

CF can be valuable for policy formation whereas it can be applied at various scales [4]. Indicatively, CF has been utilized to assess mutually different activities and systems such as tourism [7], public services [8], alternative transportation technologies [9] and knowledge sector [10]. Companies use CF to assess the environmental and sustainability performance of their products and processes [11 - 13]. Apart from application for business purposes, CF has been used to assess the impact of lifestyle of citizens/households [14 -16] regional activity [17] cities [18] and countries [19].

The reduction of CF has been highlighted as a major objective of European strategy towards environmental protection and climate change restraint. The Covenant of Mayors (CoM) is one of the most successful initiatives in Europe regarding the estimation and reduction of carbon footprint of regions. CoM is an EU-scale initiative involving a significant number of municipalities within EU. The participating municipalities are voluntarily committed to increase energy efficiency within their jurisdiction and the basic quantitative objective of the specific initiative is a $20 \%$ reduction of $\mathrm{CO}_{2}$ emissions by 2020 [20].

The objective of the specific study is the quantification of the carbon dioxide emissions in municipal level due to energy and fuel consumption. Three different municipalities were assessed with the application of three different carbon footprint estimation approaches in each one of them. The reason for assessing more than one municipalities and utilizing more than one $\mathrm{CF}$ estimation methods at the same time, is that comparison of the results is expected to provide valuable insights regarding specific sources of carbon dioxide emissions. 


\section{Methodology}

\subsection{Municipalities profile}

Three municipalities namely Municipality of Kavala (MoK), Municipality of Alexandroupolis (MoA) and Municipality of Drama (MoD) were examined in terms of their annual carbon footprint. All three municipalities are situated in the region of Eastern Macedonia and Thrace, Northeastern Greece (Figure 1). East Macedonia and Thrace region is one the thirteen administrative regions of Greece, comprising the eastern part of the region of Macedonia along with the region of Thrace and the islands of Thasos and Samothrace. It covers an area of approximately $14,160 \mathrm{~km}^{2}$ and has a population of 610,000 residents. The three municipalities were chosen due to their participation in the CoM. Consequently, the estimation and analysis of their carbon footprint was necessary in order to meet the requirements of the initiative and develop a sustainable energy action plan (SEAP).

The climate of MoK, MoA and MoD is characterized as Mediterranean, moderately continental with mild winters and hot summers, without particularly extreme temperatures. The solar energy generation potential of the specific regions is relatively lower compared with southern regions of Greece and the Aegean islands, but at a European level is still attractive $\left(>1200 \mathrm{kWh} / \mathrm{m}^{2}\right) \quad$ [21].In terms of demographic development, a population reduction is observed during the last years whereas most of their population $(>60 \%)$ is occupied in tertiary sector. Key figures regarding the profile of the municipalities are summarized in Table 1. The specific characteristics are representative for most medium sized Greek municipalities (in between 50,000 and 100,000 population).

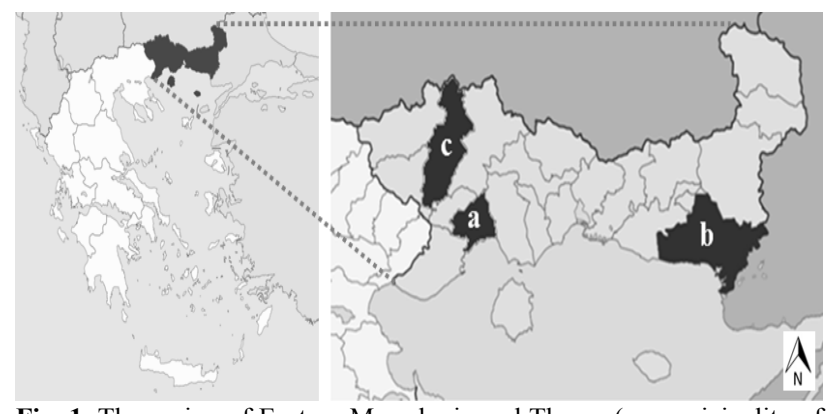

Fig. 1. The region of Eastern Macedonia and Thrace (a: municipality of Kavala, b: municipality of Alexandroupoli, c: Municipality of Drama).

Table 1. Key characteristics of the municipalities examined.

\begin{tabular}{|c|c|c|c|c|}
\hline Characteristic & Unit & MoK & MoA & MoD \\
\hline Population (2011 census) & inhabitants & 67,454 & 72,750 & 58,944 \\
\hline Population density & inhabitants $/ \mathrm{km}^{2}$ & 200.6 & 59.9 & 70.1 \\
\hline $\begin{array}{ll}\text { Temperature } & \text { range } \\
\text { (monthly average) } & \end{array}$ & ${ }^{\circ} \mathrm{C}$ & $\begin{array}{l}6.8- \\
26.5\end{array}$ & $5-26$ & $\begin{array}{l}1.3 \\
27.4\end{array}$ \\
\hline $\begin{array}{l}\text { Humidity range (monthly } \\
\text { average) }\end{array}$ & $\%$ & $\begin{array}{l}64.9- \\
68.8\end{array}$ & $\begin{array}{l}53.9- \\
76.7\end{array}$ & $\mathrm{n} / \mathrm{a}$ \\
\hline Annual precipitation & $\mathrm{mm}$ & 403 & 557 & 635 \\
\hline Men to women ratio & - & 0.98 & 1.04 & 0.92 \\
\hline $\begin{array}{l}\text { Population with MSc } \\
\text { and/or } \mathrm{PhD}\end{array}$ & $\%$ & 0.66 & 0.53 & 0.29 \\
\hline
\end{tabular}

\subsection{Carbon footprint estimation method}

There are several approaches in order to estimate the carbon footprint of a system, however most of them follow four specific general steps [22]: a) selection of the greenhouse gases to be assessed, b) setting the boundaries of the study, c) collection of the necessary data and d) translation of data into carbon footprint.
The selection of the greenhouse gases to be included in the analysis highly depends on the assessment method to be chosen, the needs of the study and the characteristics of the system under examination [22]. Several studies include only emissions of carbon dioxide for determining the carbon footprint while others include more greenhouse gases. Including all possible emissions in the analysis is a quite complicated task and therefore in most studies only the direct or first-class indirect emissions are taken into account [23]. In the specific study, three different approaches were applied that will be discussed in detail below.

Setting the boundaries of the study relates to the selection of activities whose emissions will be quantified and will be taken into account in the analysis. Since the goal of this study is the analysis of the carbon dioxide emissions of municipalities due to their energy and fuel consumption/production profile, the development of an analytical regional energy balance is necessary in order to proceed to the carbon footprint estimations. The parameters included into the carbon footprint estimations are in accordance with the CoM guidelines [24] and are presented in Table 2.

Table 2. Parameters included into the carbon footprint estimations.

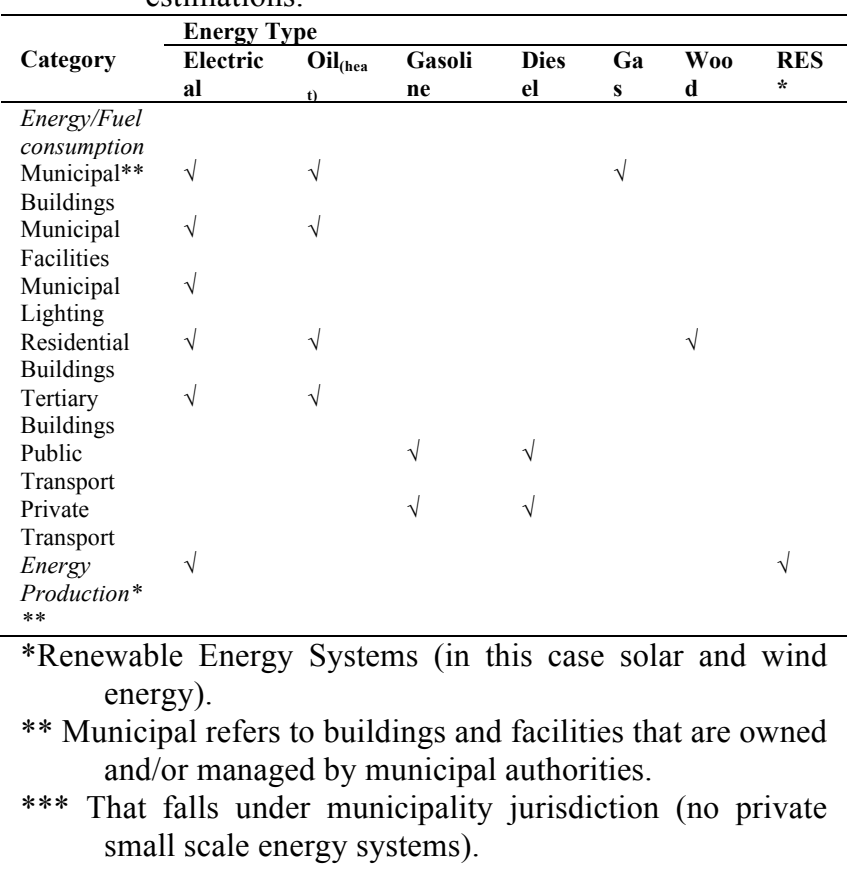

The energy consumption estimations included all basic electrical and fuel consumptions within the boundaries of the municipality. All energy sources were translated into respective $\mathrm{MWh}$ with the application of the conversion factors proposed by CoM [24]. Parameters such as energy consumption of industries, small scale private energy production etc. were not included in the analysis due to the objective of the study, since municipal authorities cannot or it is too difficult for them to interfere to the carbon footprint amelioration of these sectors.

Estimations were performed for the year 2011 (baseline year) for MoK and MoA and 2012 for MoD. Necessary data were acquired from various sources including energy audits, local authorities, online databases etc. (Table 3). Collection of all data was found to be a very time-consuming and demanding process. Data acquisition time ranged from 2 to 5 months for each municipality depending on the availability 
of existing databases, available staff, organizational structures and response time of various agents.

Table 3. Data collection sources.

\begin{tabular}{|c|c|}
\hline Building/Facilities & Electricity, Oil(heat), Wood \\
\hline $\begin{array}{l}\text { Municipal } \\
\text { buildings/facilities }\end{array}$ & $\begin{array}{l}\text { Building energy audits, data from municipal } \\
\text { authorities, PPC (public power corporation), } \\
\text { Municipal Water Supply and Drainage Company. }\end{array}$ \\
\hline $\begin{array}{l}\text { Residential/Tertiary } \\
\text { buildings }\end{array}$ & $\begin{array}{l}\text { Data were estimated based on national annual } \\
\text { consumptions acquired from national information } \\
\text { system for energy and the number of households in } \\
\text { municipalities. }\end{array}$ \\
\hline $\begin{array}{l}\text { Municipal } \\
\text { lighting }\end{array}$ & $\begin{array}{l}\text { Estimations from municipal technical services and } \\
\text { field observations. }\end{array}$ \\
\hline Transportation & Diesel/Gasoline \\
\hline Municipal fleet & Data from municipal technical service department. \\
\hline Public transport & $\begin{array}{l}\text { Local transportation cooperative i.e. KTEL, and } \\
\text { estimations based on total } \mathrm{km} \text { traveled. }\end{array}$ \\
\hline Private transport & $\begin{array}{l}\text { Statistical data from Egnatia Odos S.A., and } \\
\text { Hellenic Statistical Office, and estimations based on } \\
\text { total km traveled. }\end{array}$ \\
\hline
\end{tabular}

The final step for estimating the CF of the municipalities is the translation of respective data into carbon footprint with the application of a relative method. The choice of the appropriate method depends on the objective of the study (mandatory, voluntary, internal management), and the available time and cost. Field measurements provide the most accurate results however their implementation is undermined by high costs especially for wide systems. Consequently coefficients and emission models are usually applied for carbon footprint estimations. The following three methods were applied for the estimation of the CF of MoK, MoA and MoD:

- a) The standard emission factors method in line with the Intergovernmental Panel on Climate Change (IPCC) principles.

- b) The IPCC life cycle emission factors method.

- c) A life cycle assessment (LCA) method with the application of relative software.

The first two methods are proposed by the European Commission for the municipalities who want to estimate their baseline $\mathrm{CO}_{2}$ emissions [24]. They translate the energy inventory into $\mathrm{CO}_{2}$ emissions with the application of relative emission factors. Analytical guidelines for those who are interested in their implementation are available [24,25].

The standard emission factors are based on the carbon content of each fuel, included in the inventory of GHG United Nations Framework Convention on Climate Change (UNFCCC) and the Kyoto Protocol. According to this approach, $\mathrm{CO}_{2}$ is the most important greenhouse gas, whereas the calculation of other gases such as methane $\left(\mathrm{CH}_{4}\right)$ and nitrous oxide $\left(\mathrm{N}_{2} \mathrm{O}\right)$ is not required. In this case, the carbon footprint is expressed as tons of $\mathrm{CO}_{2}$ emissions ( $\mathrm{t}$ $\mathrm{CO}_{2}$ ).

The life cycle emission factors take into account the whole life cycle of the energy carrier. So apart from the emissions due to combustion, emissions from other life cycle stages such as extraction, supply chain and disposal are taken into account. Additionally, other greenhouse gases beyond $\mathrm{CO}_{2}$ are included in the analysis. In this case, the carbon footprint is expressed as tons of equivalent $\mathrm{CO}_{2}$ emissions ( $\mathrm{t} \mathrm{CO}_{\text {2-equivalent }}$ ).

The application of emission factors should take into account the special geographical characteristics of the system under examination. Therefore different factors and emissions models have been proposed for different areas [25]. Whenever possible, it is appropriate to use the most representative local models and indicators available. In the specific study, the emission factors for electricity were estimated based on local emission factor (EFE) equation proposed by SEAP guidelines [24] (Equation 1). The emission factors applied in this study are summarized in Table 4.

$E F E=\frac{\left[(T C E-L P E-G E P) \times N E E F E+\mathrm{CO}_{2} L P E+\mathrm{CO}_{2} G E P\right]}{T C E}$

where

$\mathrm{EFE}=$ local emission factor for electricity $\left[\right.$ in $\left.\mathrm{t} / \mathrm{MWh}_{\mathrm{e}}\right]$.

$\mathrm{TCE}=$ total electricity consumption in the local authority [in $\mathrm{MWh}_{\mathrm{e}}$.

$\mathrm{LPE}=$ local electricity production [in $\mathrm{MWh}_{\mathrm{e}}$ ].

$\mathrm{GEP}=$ green electricity purchases by the local authority [in $\left.\mathrm{MWh}_{\mathrm{e}}\right]$.

NEEFE = national or European emission factor for electricity [in $\mathrm{t} / \mathrm{MWh}_{\mathrm{e}}$ ].

$\mathrm{CO}_{2} \mathrm{LPE}=\mathrm{CO}_{2}$ emissions due to the local production of electricity [in t].

$\mathrm{CO}_{2} \mathrm{GEP}=\mathrm{CO}_{2}$ emissions due to the production of certified green electricity purchased by the local authority [in t].

Table 4. Emission factors applied in methods a and b [24].

\begin{tabular}{lll}
\hline \multirow{2}{*}{ Energy source } & Method a & Method b \\
\cline { 2 - 3 } & $\begin{array}{l}\text { Standard emission factors } \\
\left(\mathrm{tCO}_{2} / \mathrm{MWh}_{\mathrm{e}}\right)\end{array}$ & $\begin{array}{l}\mathrm{LCA} \text { emission factors } \\
\left(\mathrm{tCO}_{2 \text {-eq }} / \mathrm{MWh}_{\mathrm{e}}\right)\end{array}$ \\
\hline Electrical energy & $1.149 / 1.013 / 1.036^{*}$ & $1.167 / 1.030 / 1.055^{*}$ \\
Gasoline & 0.249 & 0.299 \\
Diesel, Heating Oil & 0.267 & 0.305 \\
Wood & 0.282 & 0.405 \\
\hline *MoK/MoA/MoD & &
\end{tabular}

The emission factors for gasoline, diesel and heating oil were taken equal to the proposed national average values for Greece. A significant amount of the wood utilized in the examined municipalities, comes from unknown sources and/or unsustainable timbering from other countries whereas inappropriate wood (planks, old furniture) may also be used. In that aspect, an emission factor higher than zero was selected.

Method c is a more complicated task. The energy/fuel flows were modeled and assessed with the application of LCA software (SimaPro 7.2). LCA assesses the environmental impact of a system, taking into account all the stages of its life cycle (manufacturing, use, disposal etc.) [26]. It is considered as a complementary and a more comprehensive tool with respect to other environmental management systems (EMS) for supporting an effective integration of environmental aspects in business and economy [27]. Four standard steps namely 1) goal and scope, 2) inventory analysis, 3) impact assessment and 4) interpretation have been developed according to the principles of ISO 14040 standard series and are available for those who wish to implement it [28].

Goal and scope step includes actions such as defining the aim, functional unit and the boundaries of the system under examination. Life cycle inventory (LCI) is a list of all raw materials, extractions and emissions during the life cycle of a system. In the specific LCA, two databases were applied in order to model the energy and fuel flows; Ecoinvent and ETH-ESU. These databases were chosen since they include many processes regarding energy production and 
transportation, they refer to European data and are widely applied.

Impact assessment is necessary for the comprehension of the inventory results. During this step, the effects of the resources used and the emissions generated are grouped and quantified into a number of impact categories. The $\mathrm{ReCiPe}$ 2008 method was applied in order to assess various impact category indicators including carbon footprint. The specific method offers the option to choose between both midpoint and endpoint indicators. Midpoint indicators focus on the environmental mechanism of an impact category (causeeffect), whereas the endpoint indicates the relative importance of the emissions or extractions [29]. Three versions of the method are available according to the time horizon and management assumptions namely the individualist (I), the hierarchist $(\mathrm{H})$ and the egalitarian $(\mathrm{E})$ perspective. The default ReCiPe midpoint method recommended by the LCA software was applied (Hierarchist, European normalization average weighting set - Europe ReCiPe H/A, V1.04). In the hierarchist perspective damages are assumed to be avoidable by good management. Analytical information regarding the characteristics and functionality of the method can be found in the relative comprehensive report [30]. Finally the results are interpreted according to the goal and scope of the study.

Analytical description of the energy and carbon footprint estimations of MoK, MoA and MoD can be found in their respective Sustainable Energy Action Plans (SEAP) [31-33].

\section{Results and Discussion}

\subsection{Carbon Footprint Assessment}

Results ranged from 511,799 to $571,000,435,250$ to 489,000

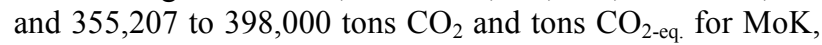
$\mathrm{MoA}$ and MoD respectively (Table 5). Corresponding values expressed in equivalent tons of $\mathrm{CO}_{2}$ per capita ranged from 7.6 to 8.5 for MoK, 6.0 to 6.7 for MoA and 6.0 to 6.8 for $\mathrm{MoD}$. The total carbon footprint per capita for MoA and $\mathrm{MoD}$ was very similar, despite the fact that their carbon footprint profiles presented noticeable differences. An increase of $7-7.5 \%$ was observed between estimations with method a-b, and 3.5-4\% between methods b-c. The specific variations are attributed to the different scope and greenhouse gases inventory included in every method due to the LCA approach. LCA results were higher, something to be expected since they include emissions from other greenhouse gases and life cycle stages.

Table 5. Total carbon dioxide emissions for every assessment method applied.

\begin{tabular}{llllll}
\hline $\begin{array}{l}\text { Assessment } \\
\text { method }\end{array}$ & \multirow{2}{*}{ Unit } & \multicolumn{3}{l}{$\begin{array}{l}\text { Carbon Footprint in tons } \mathrm{CO}_{2} \\
\text { (per capita) }\end{array}$} \\
\cline { 4 - 6 } & & MoK & MoA & MoD \\
\hline a) & $\begin{array}{l}\text { Standard emission factors } \\
\text { (IPCC) }\end{array}$ & tons $\mathrm{CO}_{2}$ & 511,799 & 435,250 & 355,207 \\
& (IPC) & & $(7.6)$ & $(6.0)$ & $(6.0)$
\end{tabular}

\begin{tabular}{llllll} 
b) LCA emission factors & tons & 549,712 & 471,094 & 384,342 \\
& (IPCC) & $\mathrm{CO}_{2 \text {-eq }}$ & $(8.1)$ & $(6.5)$ & $(6.5)$ \\
c) LCA ReCiPe method & tons & 571,000 & 489,000 & 398,000 \\
& $\mathrm{CO}_{2-\mathrm{eq}}$ & $(8.5)$ & $(6.7)$ & $(6.8)$ \\
\hline
\end{tabular}

MoK exhibited the highest carbon footprint both in absolute and per capita values for all three methods. The reason for this particular result is the complete lack of electrical energy production from RES (excluding private small scale facilities) within the boundaries of the municipality. In the case of MoA, 30,299 MWh of electricity are produced by wind and photovoltaic systems whereas for MoD the specific figure is $20,818 \mathrm{MWh}$. As a result the local emission factor for electricity (see Equation 1) is significantly higher for MoK (10-12\%) in comparison with that of MoA and MoD. Since the local emission factor is utilized to estimate all emissions from electricity consumption, significant gains result from the utilization of RES due to the reduced electrical energy coefficient. In that aspect, municipalities trying to reduce their carbon footprint should highly focus on reducing their local emission factor for electricity. Municipalities presenting low levels of RES integration can achieve significant improvement of their carbon footprint and reach their targets quickly by alternating their local energy mix in favour of RES.

The analytical carbon footprint per sector and energy type, including their contribution percentages to the total carbon footprint, with the application of methods a and $b$ are presented in Tables 6 and 7.

The analysis per energy type indicated the electrical energy consumption as the key factor affecting the results due to the relatively high $\mathrm{CO}_{2}$ emission coefficient of the electricity produced in Greece (1.149 $\left.\mathrm{C} \mathrm{CO}_{2} / \mathrm{MWh}_{\mathrm{e}}\right)$. Over half of the carbon footprint of the municipalities is attributed to electrical energy consumed to satisfy the needs of the citizens, indicating the carbon footprint "hot spot" where amelioration actions should focus firstly. Emissions from diesel utilization for transportation were higher than those of gasoline. Wood consumption (thus relative emissions) in $\mathrm{MoD}$ was higher compared to MoK and MoA despite the fact that MoD has less population. This is attributed to the spatial (open space, 1 to 2 floor buildings - multi-storey buildings only in the city centre) and climate characteristics (colder winters) of MoD and its proximity to cheaper wood imported from Bulgaria.

The economical crisis that hit Greece after 2009, significantly affected its energy consumption profile due to the increased price of domestic heating oil and gasoline. The impact of economical crisis in terms of carbon dioxide and other emissions is twofold. On the one hand the emissions are reduced due to the significantly lower consumption of diesel and the reduction of vehicle utilization for personal needs. On the other hand, people try to find cheaper ways in order to satisfy their heating needs such as electricity, timber and biomass heating systems which are characterized by notably higher emission levels per $\mathrm{kWh}_{\mathrm{th}}$.

Table 6. Carbon footprint per sector and energy type with the application of method a.

\begin{tabular}{|c|c|c|c|c|c|c|c|}
\hline \multirow{2}{*}{$\begin{array}{l}\text { Municipality of Kavala } \\
\text { Category }\end{array}$} & \multicolumn{7}{|c|}{$\mathrm{CO}_{2}$ Emissions [in tons] } \\
\hline & Electricity & Oil (heat) & Diesel & Gasoline & Wood & Total & $\%$ \\
\hline \multicolumn{8}{|l|}{ Buildings/Facilities } \\
\hline Municipal buildings/facilities & 19,402 & 2,077 & - & - & - & 21,479 & $4 \%$ \\
\hline Tertiary buildings & 150,066 & 4,753 & - & - & - & 154,819 & $30 \%$ \\
\hline Residential buildings & 151,133 & 43,072 & - & - & 14,204 & 208,408 & $41 \%$ \\
\hline Municipal public lighting & 11,558 & - & - & - & - & 11,558 & $2 \%$ \\
\hline Subtotal Buildings/Facilities & 332,159 & 49,902 & - & - & 14,204 & 396,264 & $77 \%$ \\
\hline
\end{tabular}


K. Angelakoglou, G. Gaidajis, K. Lymperopoulos and P. N. Botsaris

/Journal of Engineering Science and Technology Review 8 (4) (2015) 15 - 23

\begin{tabular}{|c|c|c|c|c|c|c|c|}
\hline \multicolumn{8}{|l|}{ Transport } \\
\hline Municipal fleet & - & - & 713 & 59 & - & 772 & $<1 \%$ \\
\hline Public transport & - & - & 1,792 & - & - & 1,792 & $<1 \%$ \\
\hline Private transport & - & - & 62,254 & 50,717 & - & 112,971 & $22 \%$ \\
\hline Subtotal transport & - & - & 64,759 & 50,776 & - & 115,535 & $23 \%$ \\
\hline Total $(\%)$ & $65 \%$ & $10 \%$ & $12 \%$ & $10 \%$ & $3 \%$ & 511,799 & $100 \%$ \\
\hline Municipality of Alexandroupoli & \multicolumn{7}{|c|}{$\mathrm{CO}_{2}$ Emissions [in tons] } \\
\hline Category & Electricity & Oil (heat) & Diesel & Gasoline & Wood & Total & $\%$ \\
\hline \multicolumn{8}{|l|}{ Buildings/Facilities } \\
\hline Municipal buildings/facilities & 5,534 & 1,768 & - & - & 2 & 7,305 & $2 \%$ \\
\hline Tertiary buildings & 110,329 & 3,964 & - & - & - & 114,292 & $26 \%$ \\
\hline Residential buildings & 140,121 & 35,918 & - & & 11,845 & 187,884 & $43 \%$ \\
\hline Municipal public lighting & 3,251 & - & - & - & - & 3,251 & $1 \%$ \\
\hline Subtotal Buildings/Facilities & 259,235 & 41,650 & - & - & 11,847 & 312,732 & $72 \%$ \\
\hline \multicolumn{8}{|l|}{ Transport } \\
\hline Municipal fleet & - & - & 925 & 53 & - & 978 & $<1 \%$ \\
\hline Public transport & - & - & 1,837 & - & - & 1,837 & $<1 \%$ \\
\hline Private transport & - & - & 69,120 & 50,583 & - & 119,703 & $28 \%$ \\
\hline Subtotal transport & - & - & 71,883 & 50,636 & - & 122,518 & $28 \%$ \\
\hline Total (\%) & $59 \%$ & $10 \%$ & $16 \%$ & $12 \%$ & $3 \%$ & 435,250 & $100 \%$ \\
\hline Municipality of Drama & \multicolumn{7}{|c|}{$\mathrm{CO}_{2}$ Emissions [in tons] } \\
\hline Category & Electricity & Oil (heat) & Diesel & Gasoline & Wood & Total & $\%$ \\
\hline \multicolumn{8}{|l|}{ Buildings/Facilities } \\
\hline Municipal buildings/facilities & 12,883 & 2,020 & - & - & - & $14,974 *$ & $4 \%$ \\
\hline Tertiary buildings & 95,010 & 3,216 & - & - & - & 98,226 & $28 \%$ \\
\hline Residential buildings & 99,609 & 69,934 & - & - & 17,193 & 186,736 & $52 \%$ \\
\hline Municipal public lighting & 12,710 & - & - & - & - & 12,710 & $4 \%$ \\
\hline Subtotal Buildings/Facilities & 220,212 & 75,170 & - & - & - & 312,646 & $88 \%$ \\
\hline \multicolumn{8}{|l|}{ Transport } \\
\hline Municipal fleet & - & - & 309 & 64 & - & 373 & $<1 \%$ \\
\hline Public transport & - & - & 1,061 & - & - & 1,061 & $<1 \%$ \\
\hline Private transport & - & - & 24,054 & 17,073 & - & 41,126 & $12 \%$ \\
\hline Subtotal transport & - & - & 25,425 & 17,079 & - & 42,564 & $12 \%$ \\
\hline Total $(\%)$ & $62 \%$ & $21 \%$ & $7 \%$ & $5 \%$ & $5 \%$ & 355,207 & $100 \%$ \\
\hline
\end{tabular}

*71 tons of $\mathrm{CO}_{2}$ due to natural gas consumption were also included in the analysis

Subtotal values may vary a little due to approximations

Table 7. Carbon footprint per sector and energy type with the application of method $\mathrm{b}$.

\begin{tabular}{|c|c|c|c|c|c|c|c|}
\hline \multirow{2}{*}{$\begin{array}{l}\text { Municipality of Kavala } \\
\text { Category }\end{array}$} & \multicolumn{7}{|c|}{$\mathrm{CO}_{2}$ Emissions [in tons] } \\
\hline & Electricity & Oil (heat) & Diesel & Gasoline & Wood & Total & $\%$ \\
\hline \multicolumn{8}{|l|}{ Buildings/Facilities } \\
\hline Municipal buildings/facilities & 19,706 & 2,373 & - & - & - & 2,079 & $4 \%$ \\
\hline Tertiary buildings & 152,417 & 5,430 & - & - & - & 157,847 & $29 \%$ \\
\hline Residential buildings & 153,500 & 49,202 & - & - & 20,399 & 223,101 & $41 \%$ \\
\hline Municipal public lighting & 11,739 & - & - & - & - & 11,739 & $2 \%$ \\
\hline Subtotal Buildings/Facilities & 337,362 & 57,004 & - & - & 20,399 & 414,765 & $76 \%$ \\
\hline \multicolumn{8}{|l|}{ Transport } \\
\hline Municipal fleet & - & - & 815 & 71 & - & 886 & $<1 \%$ \\
\hline Public transport & - & - & 2,047 & - & - & 2,047 & $<1 \%$ \\
\hline Private transport & - & - & 71,114 & 60,901 & - & 132,015 & $24 \%$ \\
\hline Subtotal transport & - & - & 73,976 & 60.972 & - & 134,974 & $24 \%$ \\
\hline Total $(\%)$ & $61 \%$ & $10 \%$ & $14 \%$ & $11 \%$ & $4 \%$ & 549,712 & $100 \%$ \\
\hline Municipality of Alexandroupoli & \multicolumn{7}{|c|}{$\mathrm{CO}_{2}$ Emissions [in tons] } \\
\hline Category & Electricity & Oil (heat) & Diesel & Gasoline & Wood & Total & $\%$ \\
\hline \multicolumn{8}{|l|}{ Buildings/Facilities } \\
\hline Municipal buildings/facilities & 5,627 & 2,020 & - & - & 3 & 7,650 & $2 \%$ \\
\hline Tertiary buildings & 112,180 & 4,528 & - & - & - & 116,708 & $25 \%$ \\
\hline Residential buildings & 142,473 & 41,030 & - & & 17,011 & 200,513 & $42 \%$ \\
\hline Municipal public lighting & 3,305 & - & - & - & - & 3,305 & $1 \%$ \\
\hline Subtotal Buildings/Facilities & 263,585 & 47,577 & - & - & 17,014 & 328,177 & $70 \%$ \\
\hline \multicolumn{8}{|l|}{ Transport } \\
\hline Municipal fleet & - & - & 1,057 & 64 & - & 1,121 & $<1 \%$ \\
\hline Public transport & - & - & 2,098 & - & - & 2,098 & $<1 \%$ \\
\hline
\end{tabular}


/Journal of Engineering Science and Technology Review 8 (4) (2015) 15 - 23

\begin{tabular}{|c|c|c|c|c|c|c|c|}
\hline Private transport & - & - & 78,958 & 60,740 & - & 139,698 & $30 \%$ \\
\hline Subtotal transport & - & - & 82,113 & 60,804 & - & 142,917 & $30 \%$ \\
\hline Total $(\%)$ & $56 \%$ & $10 \%$ & $17 \%$ & $13 \%$ & $4 \%$ & 471,094 & $100 \%$ \\
\hline Municipality of Drama & \multicolumn{7}{|c|}{$\mathrm{CO}_{2}$ Emissions [in tons] } \\
\hline Category & Electricity & Oil (heat) & Diesel & Gasoline & Wood & Total & $\%$ \\
\hline \multicolumn{8}{|l|}{ Buildings/Facilities } \\
\hline Municipal buildings/facilities & 13,109 & 2,308 & - & - & - & $15,500 *$ & $4 \%$ \\
\hline Tertiary buildings & 96,678 & 3,674 & - & - & - & 100,352 & $26 \%$ \\
\hline Residential buildings & 101,358 & 79,887 & - & - & 24,692 & 205,937 & $54 \%$ \\
\hline Municipal public lighting & 12,933 & - & - & - & - & 12,933 & $3 \%$ \\
\hline Subtotal Buildings/Facilities & 224,078 & 85,869 & - & - & - & 334.722 & $87 \%$ \\
\hline \multicolumn{8}{|l|}{ Transport } \\
\hline Municipal fleet & - & - & 353 & 77 & - & 430 & $<1 \%$ \\
\hline Public transport & - & - & 1,212 & - & - & 1,212 & $<1 \%$ \\
\hline Private transport & - & - & 24,477 & 20,501 & - & 47,978 & $13 \%$ \\
\hline Subtotal transport & - & - & 29,043 & 20,577 & - & 49,620 & $13 \%$ \\
\hline Total $(\%)$ & $58 \%$ & $22 \%$ & $8 \%$ & $5 \%$ & $7 \%$ & 384,342 & $100 \%$ \\
\hline
\end{tabular}

*83 tons of $\mathrm{CO}_{2}$ due to natural gas consumption were also included in the analysis

Subtotal values may vary a little due to approximations

The analysis per sector indicated that a percentage of nearly $75 \%$ of the total carbon footprint is assigned to the building sector whereas the private and commercial transport is accountable for the rest. Residential buildings are the sector of higher contribution (41-52\%). The specific finding is in accordance with the latest European strategies on energy efficiency highly focusing on the building stock upgrade.

Municipal activities (buildings, facilities, lighting and fleet) contribute to a small percentage to the total carbon footprint (approx. 7\%, 3\% and 8\% for MoK, MoA and MoD respectively). Consequently, municipalities should focus on acting as an exemplar for habitants, by providing motivations, ideas, information etc. regarding energy saving benefits. Spending large amounts of money for the energy upgrade of one or two municipal buildings will not have a significant positive effect to the overall carbon footprint, if the benefits from its implementation are not well documented and communicated to the public. Emissions falling under municipality's jurisdiction were lower in the case of MoA due to its more energy efficient lighting system and the lower municipal buildings energy consumption in comparison with the other two municipalities.

Method b slightly overestimates contribution of transportation sector $(\approx 2 \%$ higher than method a). This is attributed to the indirect emissions of transportation related fuel consumption that are not taken into account in method a. Moreover, MoD exhibited noticeable lower values regarding emissions from transportation. The reasoning behind that fact was that in the cases of MoK and MoA, the highway "Egnatia Odos" is included into the boundaries of the municipalities. The transportation load of MoK and MoA is much higher since Egnatia Odos is used by thousands of vehicles every day, satisfying major transportation needs in North Greece.

Similar contribution percentages were observed with the application of the LCA method (method c) presenting satisfying correlation with method b. In Figures 2-4 the LCA model developed by software is presented indicating the relative contribution of each sector to the final carbon footprint (as a percentage on the bottom left corner or as a thermometer bar on the right). Residential buildings and electricity consumption were once again indicated as the key contributors to the total carbon footprint of the municipalities. The impact of "Egnatia Odos" to the transportation subtotal should be mentioned (Figures 2 and $3)$, noticeably affecting the final results $(7-10.7 \%$ to total carbon footprint).

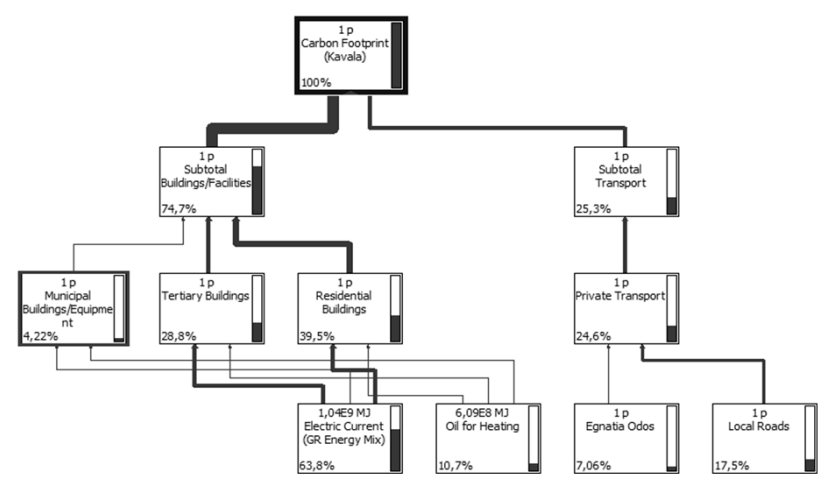

Fig. 2. Model developed in LCA software to assess the carbon footprint of MoK.

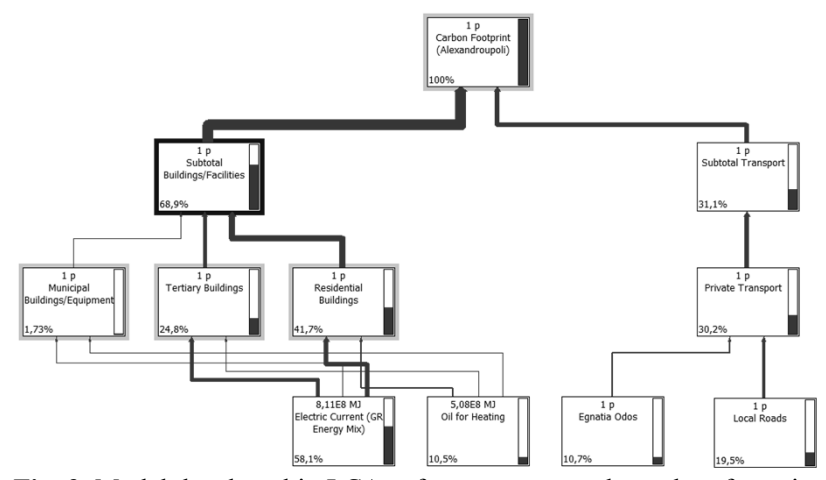

Fig. 3. Model developed in LCA software to assess the carbon footprint of MoA. 


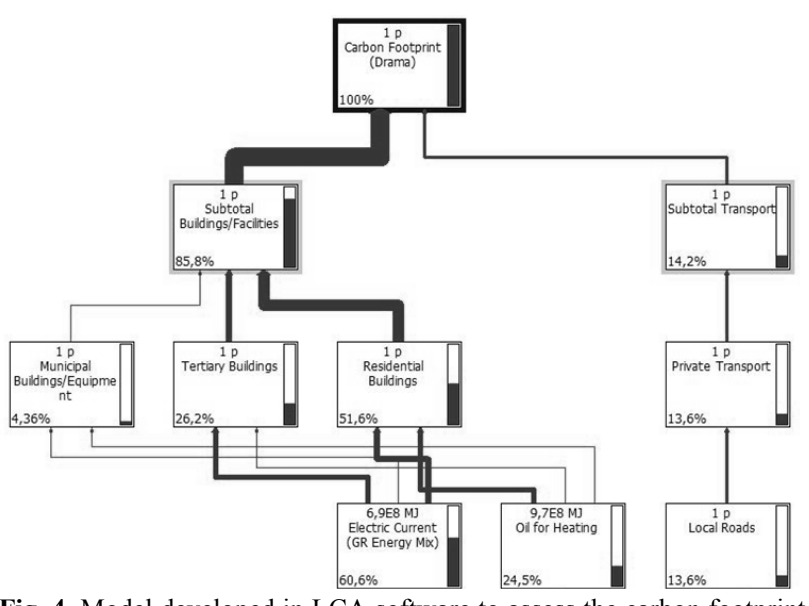

Fig. 4. Model developed in LCA software to assess the carbon footprint of MoD.

A significant advantage of implementing a LCA model to assess the carbon footprint of the municipalities was that various impact categories can be examined in parallel with carbon footprint at the same time. In Table 8 the LCA results with the application of the midpoint ReCiPe 2008 method are presented. Eighteen (18) impact categories were quantified; their analysis though is out of the scope of the specific study. However a significant observation was made. Municipalities exhibited varying performance in each impact category and especially in those related with toxic emissions and land use. The utilization of higher quantities of wood for heating has been identified as a key parameter contributing to impact categories related with the specific issues. Specific energy mix profiles may favour carbon footprint estimation in comparison with other impact categories. This is in accordance with the study of Laurent et al. [34]who investigated the correlation between $\mathrm{CF}$ and 13 impact categories, arguing that some environmental impacts, especially those related to emissions of toxic substances, often do not keep up with climate change impacts. In that aspect focusing only to $\mathrm{CF}$ for decision making may result in shifting the problem to other environmental impacts [34]. Further analysis on this aspect is needed to extract safer results.

Table 8. LCA results with the application of the midpoint ReCiPe 2008 method.

\begin{tabular}{|c|c|c|c|c|}
\hline Impact category & Unit & MoK & MoA & MoD \\
\hline Climate change & $\mathrm{kg} \mathrm{CO}_{2}$ eq. & $5.71 \times 10^{8}$ & $4,89 \times 10^{8}$ & $3,98 \times 10^{8}$ \\
\hline Ozone depletion & kg CFC-11 eq. & $2.00 \times 10^{2}$ & $1,67 \times 10^{2}$ & $2,01 \times 10^{2}$ \\
\hline Human toxicity & $\mathrm{kg} 1,4-\mathrm{DB}$ eq. & $6.29 \times 10^{7}$ & $5,25 \times 10^{7}$ & $5,44 \times 10^{7}$ \\
\hline Photochemical oxidant formation & kg NMVOC & $2.84 \times 10^{6}$ & $2,55 \times 10^{6}$ & $1,94 \times 10^{6}$ \\
\hline Particulate matter formation & $\mathrm{kg} \mathrm{PM}_{10}$ eq. & $1.72 \times 10^{6}$ & $1,44 \times 10^{6}$ & $1,30 \times 10^{6}$ \\
\hline Ionising radiation & $\mathrm{kg} \mathrm{U}^{235}$ eq. & $2.68 \times 10^{7}$ & $2,23 \times 10^{7}$ & $2,16 \times 10^{7}$ \\
\hline Terrestrial acidification & $\mathrm{kg} \mathrm{SO}_{2}$ eq. & $6.59 \times 10^{6}$ & $5,39 \times 10^{6}$ & $5,02 \times 10^{6}$ \\
\hline Freshwater eutrophication & $\mathrm{kg} P$ eq. & $6.04 \times 10^{3}$ & $6,53 \times 10^{3}$ & $3,91 \times 10^{3}$ \\
\hline Marine eutrophication & $\mathrm{kg} \mathrm{N}$ eq. & $6.86 \times 10^{5}$ & $6,43 \times 10^{5}$ & $4,31 \times 10^{5}$ \\
\hline Terrestrial ecotoxicity & $\mathrm{kg} 1,4-\mathrm{DB}$ eq. & $1.43 \times 10^{5}$ & $1,23 \times 10^{5}$ & $1,47 \times 10^{5}$ \\
\hline Freshwater ecotoxicity & kg $1,4-\mathrm{DB}$ eq. & $2.53 \times 10^{5}$ & $2,63 \times 10^{5}$ & $1,73 \times 10^{5}$ \\
\hline Marine ecotoxicity & kg $1,4-\mathrm{DB}$ eq. & $6.40 \times 10^{5}$ & $5,95 \times 10^{5}$ & $5,58 \times 10^{5}$ \\
\hline Agricultural land occupation & $\mathrm{m}^{2} \times \mathrm{yr}$ & $3.11 \times 10^{7}$ & $2,60 \times 10^{7}$ & $3,76 \times 10^{7}$ \\
\hline Urban land occupation & $\mathrm{m}^{2} \times \mathrm{yr}$ & $6.53 \times 10^{5}$ & $6,60 \times 10^{5}$ & $5,29 \times 10^{5}$ \\
\hline Natural land transformation & $\mathrm{m}^{2}$ & $7.60 \times 10^{4}$ & $7,78 \times 10^{4}$ & $3,25 \times 10^{4}$ \\
\hline Water depletion & $\mathrm{m}^{3}$ & $1.60 \times 10^{7}$ & $1,25 \times 10^{7}$ & $1,08 \times 10^{7}$ \\
\hline Metal depletion & $\mathrm{kg} F e$ eq. & $3.65 \times 10^{6}$ & $3,78 \times 10^{6}$ & $3,06 \times 10^{6}$ \\
\hline Fossil depletion & kg oil eq. & $1.99 \times 10^{8}$ & $1,73 \times 10^{8}$ & $1,32 \times 10^{8}$ \\
\hline
\end{tabular}

\subsection{Comparison with other Municipalities}

According to the European Joint Research Centre (JRC) the average $\mathrm{CO}_{2}$ emissions in EU27 for 2011 were 7.5 tons per capita [35]. Mediterranean countries like Italy (6.7 tons) and Spain (6.4 tons) exhibited lower average emissions. Regarding Greece, reliable data are available for the year 2008 that set its carbon footprint to 8.6-8.8 tons per capita $[36,37]$. The results presented in this study are slightly lower compared with these figures. If emissions from other sources were additionally taken into account (i.e. industrial/agricultural activities), results would be much closer to the average values for Greece mentioned above. It should be noted however that comparisons between various studies entail high levels of uncertainty as they rely on different methodological approaches, cut-off criteria and allocation procedures.
In Table 9 the carbon footprint per capita of all Greek municipalities that have submitted a SEAP is presented. In total 52 municipalities had submitted an action plan until $31 / 1 / 2014$ of which 48 were available to extract their carbon footprint [38]. All municipalities have applied the standard emission factors (method a) to estimate their carbon footprint. Baseline year ranged from 2005 to 2012 . Significant deviations were observed basically due to the different boundaries set by a number of municipalities (e.g. only including municipal activities and not residential/tertiary sector, transportation assumptions), data collection methods and municipality profile (e.g. extensive industrial activity such as Aspropyrgos). The average carbon footprint for all municipalities examined was 6.8 tons per capita which is in accordance to Mediterranean countries norm and the findings of this study.

Table 9. Carbon footprint (in tons $\mathrm{CO}_{2}$ per capita) of Greek municipalities according to their SEAP submitted to CoM (presented in alphabetical order).

\begin{tabular}{lllll}
\hline Name of Municipality & Carbon footprint & Name of Municipality & Carbon footprint & Name of Municipality \\
\hline Agia & 4.5 & Ilion & 4.3 & Monemvasia \\
Agia Varvara & 5.5 & Ilioupolis & 5.0 & 1.7 \\
forint & 5.9 & Moudros
\end{tabular}




\begin{tabular}{|c|c|c|c|c|c|}
\hline Aigaleo & 6.8 & Ios & 8.0 & Nea Smyrni & 5.3 \\
\hline Alexandroupoli & 6.0 & Kalamaria & 4.4 & Neapolis Sykies & 4.0 \\
\hline Amaroussion & 8.1 & Kavala & 7.6 & Nisyros & 3.8 \\
\hline Amynteo & 8.2 & Kea & 6.7 & Notia Kynouria & 3.5 \\
\hline Aspropyrgos & 56.4 & Korthi & 5.9 & Oia & 11.5 \\
\hline Chalkidona & 4.0 & Kozani & 6.6 & Patra & 4.9 \\
\hline Rethymno & 2.9 & Lagadas & 3.8 & Pavlos Melas & 4.1 \\
\hline Dionysos & 7.6 & Leros & 5.7 & Pilea Hortiatis & 5.8 \\
\hline Drama & 6.0 & Lipsi & 4.7 & Poseidonia & 7.7 \\
\hline Edessa & 5.7 & Loutraki & 10.4 & Skyros & 7.0 \\
\hline Eurotas & 7.8 & Megara & 7.3 & Thermaikos & 7.6 \\
\hline Festos & 12.6 & Messini & 5.2 & Thermi & 2.2 \\
\hline Haidari & 0.1 & Minoa Pediadas & 6.8 & Trikala & 0.5 \\
\hline Heraklion & 4.0 & Moschato Tavros & 6.8 & Vrilissia & 6.3 \\
\hline \multirow{2}{*}{\multicolumn{5}{|c|}{$\begin{array}{l}\text { Average of all Greek municipalities } \\
\text { Median of all Greek municipalities }\end{array}$}} & 6.8 \\
\hline & & & & & 5.9 \\
\hline
\end{tabular}

\section{Conclusions}

In the specific study, three municipalities in North Greece namely Municipality of Kavala (MoK), Municipality of Alexandroupolis (MoA) and Municipality of Drama (MoD) were assessed in terms of carbon dioxide emissions due to energy and fuel consumption within their boundaries. Three different carbon footprint estimation approaches were applied in each one of them: a) the standard emission factors method in line with the Intergovernmental Panel on Climate Change (IPCC) principles, b) the IPCC life cycle emission factors method and c) A life cycle assessment method with the application of relative software. Summarizing the results, the following conclusions can be drawn:

- $\quad$ Results ranged from 511,799 to $571,000,435,250$ to 489,000 and 355,207 to 398,000 tons $\mathrm{CO}_{2}$ and tons $\mathrm{CO}_{2 \text {-eq. }}$ for $\mathrm{MoK}, \mathrm{MoA}$ and $\mathrm{MoD}$ respectively. Corresponding values expressed in equivalent tons of $\mathrm{CO}_{2}$ per capita ranged from 7.6 to 8.5 for $\mathrm{MoK}$, 6.0 to 6.7 for $\mathrm{MoA}$ and 6.0 to 6.8 for $\mathrm{MoD}$ in accordance to Mediterranean countries norm.

- The analysis per energy type indicated the electrical energy consumption as the key factor affecting the results due to the relatively high $\mathrm{CO}_{2}$ emission coefficient of the electricity produced in Greece (1.149 $\mathrm{t} \mathrm{CO}_{2} / \mathrm{MWh}_{\mathrm{e}}$ ).

- The analysis per sector indicated that a percentage of nearly $75 \%$ of the total carbon footprint is assigned to the building sector whereas the private and commercial transport is accountable for the rest. Residential buildings were the sector of higher contribution (41-52\%).

- Municipal activities (buildings, facilities, lighting and fleet) contributed to a small percentage to the total carbon footprint (approx. 7\%, 3\% and 8\% for MoK, MoA and MoD respectively). Consequently, municipalities should focus on acting as an exemplar for habitants, by providing motivations, ideas, information etc. regarding energy saving benefits.

- LCA methods slightly overestimate contribution of transportation sector. This is attributed to the indirect emissions of transportation related fuel consumption.

- Municipalities exhibited varying performance in impact categories other that climate change and especially in those related with toxic emissions and land use. Focusing only on CF for decision making may result in shifting the problem to other environmental impacts. The specific conclusion should be taken into account into policy development.

The development of an analytical energy balance and the estimation of its respective carbon footprint for a municipality can be a challenging and long task, provides however a useful management tool for the municipal authorities, significantly strengthens the adoption of effective regional strategies, communication of the results and the participation in relative programs and financing. The specific study is expected to be useful for municipal authorities, public agents, decision-makers and stakeholders interested in the assessment and improvement of carbon dioxide related aspects in municipal level.

\section{Acknowledgements}

The authors would like to acknowledge the assistance of the stuff of the municipalities in the implementation of the study.

\section{References}

1. Finkbeiner, M. 2009. "Carbon footprinting - opportunities and threats." International Journal of Life Cycle Assessment 14: 91-94. doi:10.1007/s11367-009-0064-x.

2. Freund, P., Bachu, S., Simbeck, D., Thambimuthu, K. and Gupta M. 2012. Properties of CO2 and carbon-based fuels, IPCC special report on carbon dioxide and storage. Annex I: Properties of $\mathrm{CO} 2$ and carbon-based fuels, pp. 384-400. Retrieved from http://www.ipcc.ch/pdf/special-reports/srces/srccs annex1.pdf

3. Cucek, L., Klemes, J.J., and Kravanja, Z. 2012. "A Review of Footprint analysis tools for monitoring impacts on sustainability."
Journal of Cleaner Production 34: 9-20. doi:10.1016/j.jclepro.2012.02.036.

4. Peters, G. P. 2010. "Carbon footprints and embodied carbon at multiple scales." Current Opinion in Environmental Sustainability 2 (4): 245-250. doi:10.1016/j.cosust.2010.05.004.

5. Wiedmann, T., and Minx, J. 2008. A Definition of Carbon Footprint. In: C. C. Pertsova, Ecological Economics Research Trends: Chapter 1, pp. 1-11, Nova Science Publishers, Hauppauge NY, USA.

6. WRI/WBCSD 2004. The greenhouse gas protocol: A corporate accounting and reporting standard revised edition. Geneva: World 
Business Council for Sustainable Development and World Resource Institute. from http://www.ghgprotocol.org/files/ghgp/public/ghg-protocolrevised.pdf

7. Dwyer, L., Forsyth, P., Spurr, R., and Hoque, S. 2010. "Estimating the carbon footprint of Australian tourism." Journal of Sustainable Tourism 18 (3): 355-376. doi: 10.1080/09669580903513061.

8. Larsen, H.N., and Hertwich, E.G. 2011. "Analyzing the carbon footprint from public services provided by counties." Journal of

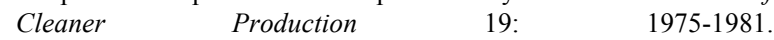
doi:10.1016/j.jclepro.2011.06.014.

9. Dunlap, R.A. 2013. "A Simple and Objective Carbon Footprint Analysis for Alternative Transportation Technologies." Energy and Environment Research 3(1): 33-39. doi:10.5539/eer.v3n1p33.

10. Chowdhury, G. 2010. "Carbon footprint of the knowledge sector: what's the future?" Journal of Documentation 66 (6): 934-946. doi: 10.1108/00220411011087878.

11. Boguski, T.K. 2010. "Life cycle carbon footprint of the National Geographic magazine." International Journal of Life Cycle Assessment 15: 635-643. doi: 10.1007/s11367-010-0210-5.

12. Jensen, J.K. 2012. "Product carbon footprint developments and gaps." International Journal of Physical Distribution \& Logistics Management 42 (4): 338-354. doi:10.1108/09600031211231326.

13. Scipioni, A., Manzardo, A., Mazzi, A., and Mastrobuono, M. 2012. "Monitoring the carbon footprint of products: a methodological proposal." Journal of Cleaner Production 36: 94-101. doi:10.1016/j.jclepro.2012.04.021.

14. Fan, J., Guo, X., Marinova, D., Wu, Y., and Zhao, D. 2012. "Embedded carbon footprint of Chinese urban households: structure and changes." Journal of Cleaner Production 33: 50-59. doi:10.1016/j.jclepro.2012.05.018.

15. Tukker, A., and Jansen, B. 2006. "Environment impacts of products - a detailed review of studies." Journal of Industrial Ecology 10: 159-182. doi: 10.1162/jiec.2006.10.3.159.

16. Weber, C., and Matthews, H.S. 2008. "Quantifying the global and distributional aspects of American household carbon footprint." Ecological Economics 66: 379-391. doi:10.1016/j.ecolecon.2007.09.021.

17. Curry, R., and Maguire, C. 2011. "The use of Ecological and Carbon Footprint Analysis in regional policy making: application and insights using the REAP model." Local Environment: The International Journal of Justice and Sustainability 16 (9): 917-936. doi: 10.1080/13549839.2011.615306.

18. Minx, J., Baiocchi, G., Wiedmann, T., Barrett, J., Creutzig, F., Feng, K., ... and Hubacek, K. 2013. "Carbon footprints of cities and other human settlements in the UK." Environmental Research Letters 8, 035039 (10pp). doi:10.1088/1748-9326/8/3/035039.

19. Aichele, R., and Felbermayr, G. 2012. "Kyoto and the carbon footprint of nations." Journal of Environmental Economics and Management 63: 336-354. doi:10.1016/j.jeem.2011.10.005.

20. Covenant of Mayors. 2014. Covenant of Mayors - Committed to local sustainable energy. Retrieved from http://www.eumayors.eu/index_en.html

21. Eurostat. 2010. Eurostat regional yearbook 2010, Eurostat statistical books, European Union, Publications office of the European Union, Luxemburg. Retrieved from http://epp.eurostat.ec.europa.eu/cache/ITY OFFPUB/KS-HA-10001/EN/KS-HA-10-001-EN.PDF

22. Pandey, D., Agrawal, M. and Pandey, J.S. 2011. "Carbon footprint: current methods of estimation." Environmental Monitoring Assessment 178: 135-160. doi: 10.1007/s10661-010-1678-y.

23. Matthews, H.S., Hendrickson, C.T. and Weber, C.L. 2008. "The importance of Carbon Footprint Estimation boundaries." Environmental Science and Technology 42: 5839-5842. doi:10.1021/es703112w.
24. European Commission. 2010. How to develop a sustainable energy action plan - guidebook. Publications office of the European Union, Luxemburg. $\quad$ Retrieved from http://www.eumayors.eu/IMG/pdf/seap_guidelines_en.pdf

25. Intergovernmental Panel on Climate Change. 2006. Intergovernmental panel on climate change Guidelines. Retrieved from http://www.ipcc-nggip.iges.or.jp/public/2006gl/index.html

26. Environmental Protection Agency. 2006. Life Cycle Assessment: Principles and Practice. Scientific Applications International Corporation (SAIC), Contract No. 68 C02-067, Work Assignment 3-15, EPA/600/R-06/060. Retrieved from http://www.epa.gov/nrmrl/std/lca/pdfs/chapter1_frontmatter_lca101 .pdf

27. Frankl, P. 2002. Life cycle assessment as a management tool, in: R.U. Ayres, L.W. Ayres (Eds.), A handbook of Industrial Ecology, Edward Elgar Publishing, pp. 530.

28. UNEP/SETAC. 2005. Life cycle approaches - the road from analysis to practice, UNEP/SETAC Life Cycle Initiative, United Nations Environment Programme, Division of Technology, Industry and Economics, Paris, France.

29. Bare, J.C., Hofstetter, P., Pennington, D.W., and Udo de Haes, H. 2000. "Midpoints versus Endpoints: The sacrifices and benefits." Life cycle impact assessment workshop summary. International Journal of LCA 5 (6): 319-326.

30. Goedkoop, M., Heijungs, R., Huijbregts, M., Schryver A., Struijs, J., and van Zelm, R. 2009. ReCiPe 2008, A life cycle impact assessment method which comprises harmonized category indicators at the midpoint and the endpoint level, first ed., Ministry of housing, spatial planning and environment (VROM), Den Haag. $\begin{array}{lll}\text { Retrieved from http:/www.pre- } & \end{array}$ sustainability.com/download/misc/ReCiPe_main_report_final_2702-2009 web.pdf

31. MoK Sustainable Action Plan. 2014. Sustainable Action Plan of the municipality of Kavala, submitted to the Covenant of Mayors. Retrieved from
f http://www.eumayors.eu/about/signatories_en.html?city_id $=2557 \&$ seap

32. MoA Sustainable Action Plan. 2014. Sustainable Action Plan of the municipality of Alexandroupolis, submitted to the Covenant of $\begin{array}{lll}\text { Mayors. } & \text { Retrieved }\end{array}$ http://www.eumayors.eu/about/signatories_en.html?city_id $=3690 \&$ seap

33. MoD Sustainable Action Plan. 2014. Sustainable Action Plan of the municipality of Drama, submitted to the Covenant of Mayors. Retrieved from http://www.eumayors.eu/about/signatories_en.html?city_id=4395\& seap

34. Laurent, A., Olsen, S.I., and Hauschild, M.Z. 2012. "Limitations of Carbon Footprint as Indicator of Environmental Sustainability." Environmental Science and Technology 46: 4100-4108. doi:10.1021/es204163f.

35. Olivier, J.G.J., Maenhout, G.J., and Peters, J.A.H.W. 2012. Trends in Global $\mathrm{CO}_{2}$ emissions. Joint Research Centre, PBL Netherlands Environmental Assessment Agency, The Hague/Bilthoven.

36. Joint Research Centre. 2013. Joint Research Centre, EDGAR Emission database for Global Atmospheric Research. Retrieved from http://edgar.jrc.ec.europa.eu/overview.php? $\mathrm{v}=\mathrm{CO} 2$

37. The World Bank. 2013. $\mathrm{CO}_{2}$ emissions (metric tons per capita). Retrieved http://data.worldbank.org/indicator/EN.ATM.CO2E.PC

38. Sustainable Energy Action Plans. 2014. Retrieved from http://www.eumayors.eu/actions/sustainable-energy-actionplans en.html?city $=$ Search + for $+\mathrm{a}+$ Sustainable + Energy + Action $+\mathrm{Pl}$ $\underline{\text { an...\&country_seap }=\text { gr } \& \text { co } 2=\& \text { date_of approval }=\& \text { accepted }=}$ 